\title{
The Functions of Women Branches in Political Parties, in Terms of Social Entrepreneurship Activities- A Case Study from Izmir-TURKEY
}

\author{
Dincer Yarkin \\ Independent Researcher, Izmir-Turkey
}

Aylin Goztas

Ege University, Izmir-Turkey

Fusun Topsumer

Ege University, Izmir-Turkey

Nuket Aygen

Phd Student in Ege University, Izmir-Turkey

Ozlem Cosan

Phd Student in Ege University, Izmir-Turkey

\begin{abstract}
In the solution of some social and economic challenges where the States, governments become short. The persons or groups that activate in order to maintain their responsibilities to the membered community are called as Social Entrepreneurs. Issues such as poverty, environmental pollution, women and child abuse, human rights violations, unemployment, refugee and immigrant rights and their integration, and minority rights are the main subjects that Social entrepreneurs are involved in finding solutions. In this study, representatives of women's branches of political parties operating in Izmir both in power and opposition were elected by random sampling and in-depth interview chosen as research method. As a result of the interviews, the activities related to social entrepreneurship dimension were evaluated. Findings showed that the political party women's branches have access to resources, and they conduct social entrepreneurship activities to solve problems in a shorter way by removing the bureaucracy as much as possible.
\end{abstract}

Keywords: Social Entrepreneurship, Political Parties, Woman Social Entrepreneurs.

\section{Introduction}

In every part of time Women have struggled to make themselves receptive in the society which they live in. They have fought against discrimination, and they have tried to explain that they are individuals. Women have always been hidden heroes of many social changes in the world. With these experiences, women are the most sensitive individuals against all the negativities that occur in society.

Social entrepreneurship activities do not belong to non-governmental organizations. However, there are number of studies in the literature about the fact that big businesses and organizations also play an active role in these activities. Foundations, fellowship organizations, network builders such as Skoll Foundation, Ashoka, CAN are the organizations which are working for promoting benefits of social entrepreneurship, affecting policy makers and creating awareness in the society (Nicholls, 2010).

Political parties offer various products to various sections of the public, to meet their needs and requests, by explaining the resources would be used, as they indicated in their party programs (Islamoglu, 2002 Divanoglu, 2008). But in reality they generally cannot be fully successful. While they can satisfy one part of the society, they can make the other unhappy. At 
this point NGO's and social entrepreneurs should be in charge. In order to provide the desired benefit, some resources needed for these actors. In practice It is not easy to reach these resources. Women Branches of Political Parties identify problems more easily because they are as isolated as politicians and because of officially member of a political party, they easily reach the resources and Women are individuals who have the power of repression within the party.

\section{Literature Review}

Social entrepreneurship distinguishes itself from other types of entrepreneurship, because priority of this type entrepreneurship is social benefit, social welfare to the human community than capturing economic value (Mair \& Marti, 2005; Peredo \& Mclean 2006). Social entrepreneurs are also facing the problem of resource scarcity and they have pressure on them to make right decision to create social value in return rather than personal wealth for the leadermanager(Chell, 2007).

Social entrepreneurship is innovative way of to deal with complex social needs which society always needs (Dess, 2001; Peredo\& McLean, 2006). Social entrepreneurs realize the social disruptions that arise in the society they live in, and they combine social innovation, responsibility and sustainability principles in order to create a social value (Denizalp, 2007; Wolk, 2008; Gorun \& Kara, 2010). Social entrepreneurs are those, who define a gap and associate it with an opportunity, in order to find resources needed, and come over the obstacles (Thompson, 2002).

According to Austin, Stevenoson \& Wei-Skillern (2006) "social entrepreneurship as innovative, social value creating activity that can occur within or across the nonprofit, business, or government sectors". Social entrepreneurship is an activity that creates products and services that address the basic human needs that existing economic and social institutions can not meet (Seelos and Mair, 2005). According to another definition, social entrepreneurship is the gathering of resources to create value (Mair and Marti, 2006) The primary objectives of social entrepreneurs are individuals, groups or organizations to whom they provide innovative solutions based on volunteering for the social, economic and cultural well-being of the nation rather than providing financial profitability personally (Leadbeater, 1997; Zadek and Thake 1997; Shaw and Carter, 2007)

The characteristics of social entrepreneurs can be listed as follows (Sanger and Levin, 1992; Noruzi, Westhover, Rahimi, 2010)Social entrepreneurs are not only composed of individuals, but also various teams, social networks and communities can be defined as social entrepreneurs. They are looking for sustainable, large-scale change. Social entrepreneurs' priority is to create social value. Certo \& Miller (2008) defines social value as meeting the long-standing needs of society's water, food, housing, education and health care. Guler (2011) summarizes basic features of social entrepreneurship as; To be able to notice social problems, draw attention to social needs,

To have a mission to create social value, to double or triple

(Economic, social and / or environmental oriented) organization, problem solving

To adopt innovative approaches to the solution of problems,

Do not accept restrictions on sources

Commercial entrepreneurs have tendency to gain value from their investments, while social entrepreneurs are struggling to use the funds provided to them within certain limits, legal regulations and short periods to meet the needs of the target groups (Letts, Grossman and Ryan, 1999, Austin, Stevenson and Wei -Skillern, 2006).

\section{Women Branches in Political Parties}

Women came out massively to the scene of history during French Revolution for equality, freedom (Gokcimen, 2008). In Turkey, The women's movement has been started since the second half of the 19th century under Ottoman Empire. Reformist transformation on law end education, made the women actively engage the life outside of their house (Caha, 1996). During Sultan Abdulhamit's time reforms on education revealed two different types of women: worker and intellectual women. These women are the founders of the politicization of women (Hotar, 2003). According to Kuyaksil (2009), if we compare the Western civilization with the Turks about implementation of human rights and women rights before the 18th century, it is possible to declare that improvement of human rights in Turkish Civilization was relatively beyond the West. In the $5^{\text {th }}$ of December, 1934 Turkish Women had right to vote and to be elected. 


\section{Methodology}

The aim was to investigate and find out the roles of Women Branches in Political Parties in the context of social entrepreneurship. Their capabilities and abilities of acting as social entrepreneurs in their political parties analysed. According to our literature review, there were no specific studies conducted related with social entrepreneurship in the context of women and political parties. Because of exploratory nature, in depth interviews was chosen as research method. Purposive sampling approach was used and 4 participants from power and opposite parties selected. Series of 4 interviews made with the participants. The duration of interviews was approximately 30 minutes duration per participant. Collected data inductively analysed. Quotas and themes were revealed according to transcribed documents. To support our research, activity reports of women branches of political parties, have also been examined. Limitations of this study are; limited number of interviewees, chosen city, and only two parties selected from 4 parties represented in Turkish parliament. Our next step with this study, is to cover all parties and whole country to generalize the findings of our study.

\section{Findings and Conclusion}

All interviewees define themselves as social entrepreneurs and they have the same idea of NGO's are more effective than the women branches of political parties. But they do not deny the social entrepreneurial role of women members. They find solutions for social problems as they get to the upper levels. We found two main themes, Bridge Between Society and Authorities in order to Create Value, Acting as Pressure Group.

\section{Bridge Between Society and Authorities in order to Create Social Value}

"We as social entrepreneurs have gathered data by listening to these problems and transmitted them to the upper authorities, ie lawmakers" (HU, Power)

"I believe that being a member of a political party will be effective in solving social problems. "I have worked both in Ak Party and civil society. I am still Secretary General of KADER (Association for Supporting Women Candidates). I think civil societies are more effective in solving social problems. Because neutrality can open up more doors, and NGOs are better able to express themselves in public interest"(AE, Power)

"I did not see the advantage of this. I believe that social entrepreneurship is a subject that should not go by using authority and with mutual tolerance. In this regard, I believe in equal opportunity". (AE, Power)

I am not a member, but I think that being in the management team is a serious influence. They were opening doors for people and institutions because I was the vice president of the political party. I participated in projects on children with disabilities. As the Capital City Women's Platform, we organized vocational courses for the parents of the handicapped children. It was a job for women's employment and it was very effective" (SY, Power)

While the mission of business entrepreneurs is to make money, the mission of social entrepreneurs is to provide social benefits (Mort, Weerawardena \& Carneige, 2002). They also play a role in policy development to ensure that this social benefit is permanent by using their credibility ( Lewis, 1980; King \& Roberts, 1987).

\section{Acting as Pressure Group}

"Top level members of political parties are beneficial to the 1st circle in their surroundings, rather than others. Even if these people can be reached, social issues lag behind the politicians' agenda. As a social entrepreneurs, we have to look for and remind politicians repeatedly for a solution of social issues" (FT, Opposite)

During the first years of the AK Party, social work for disabled people in women's branches have been effective during the process of legislation for disabled people"(HU, Power)

According to Bornstein (2004) social entrepreneurs are those "with new ideas to address major problems who are relentless in the pursuit of their visions. And Entrepreneurial activities require effective use of resources, and correctly managing of network relations, it should not be ignored that, entrepreneurship socially embedded in network structures (Aldrich and Zimmer, 1987; Casson \& Della Giusta, 2007). Politicians are under pressure of providing social justice, social equality and be sensitive to the environment, (Bernauer and Caduff 2004). Due to their social entrepreneurial characteristics, and close distance to authorities, women members of political party's may act as pressure groups in their own organizations. 
Below quotation shows us that, women in branches of political parties actively engaged in social issues. By these efforts, they expected votes also in return.

"I witnessed women in rural areas like Diyarbakır, Urfa and Balikesir working more self-sacrificing and willing in social issues. I saw these women climbing the hills to win one vote more" (AE, Power)

Especially transformation from industrial society to the information society, entrepreneurship has been gained importance in the world and 1980's the period when women's entrepreneurship begins to increase more than men's. (Soysal, 2010). Despite these efforts of women, the necessary support is not provided. When the subject comes to social entrepreneurship, especially in developing countries like Turkey, the situation is changing. Seeing women as social entrepreneurs is a positive, acceptable and supported situation in the society.

It is not only the main motivation for members of the party women's movement to increase the voting potential. Social and economic problems in the various layers of society are one of the attracting factors in adopting the social entrepreneurial role of them, the ease of accessing resources to solve as a member of a party, is more crucial.

Power party members mainly focus on, dissemination of women entrepreneurship, providing scholarships to students in need, financial support for widows and unemployed women. One of the basic reason of their vote potential will be close relations between society. Opposite party members mainly focus on women rights, women and child abuses, and intensively political issues. These results are also should be investigated in the context of political marketing.

\section{References}

[1] Aldrich, H.,E. (1987) "The Impact of Social Networks on Business Founding and Profit: A Longitudinal Approach" in Frontiers of Entrepreneurship Research. Wellesley, MA: Babson College.

[2] Austin, J., Stevenson H., \& Wei-Skillern, J. (2006) Social and Commercial Entrepreneurship: Same, Different, or Both? Entrepreneurship Theory and Practice, 30(1): 1-22.

[3] Bernauer, T., L. Caduff. 2004. In whose interest? Pressure group politics, economic competition and environmental regulation. J. Public Policy, 24(1): 99-126.

[4] Bornstein, D. (2004). How to change the world: Social entrepreneurs and the power of new ideas. NewYork:

[5] Oxford University Press.

[6] Caha, O. (1996) Sivil Kadın, Türkiye'de Sivil Toplum ve Kadın, Vadi Yayınları, Ankara.

[7] Casson, M., \& Della Giusta, M. (2007) Entrepreneurship and Social Capital. Analysing the Impact of Social Nrtworks on Entrepreneurial Activity from a Rational Action Perspective. International Small Business Journal, 25(3): 220-244.

[8] Certo, T.,S., Miller, T. (2008) Social Entrepreneurship:Key issues and concepts. Business Horizons, 51: 267271.

[9] Chell, E. (2007) Social Enterprise and Entrepreneurship. Towards a Convergent Theory of the Entrepreneurial Process. International Small Business Journal. (25) 1: 5-26.

[10] Denizalp, H. (2007), Toplumsal Dönüşüm için Sosyal Girişimcilik Rehberi, Sivil Toplum Geliştirme Merkezi Yayını, Odak Ofset Matbaacilık, Ankara.

[11] DESS,G.,J. (2001), “The Meaning of Social Entrepreneurship. Retrieved from http://www. fuqua. duke. edu/centers/case/documents/dees_sedef. pdf. Date: 26th. Dec. 2016.

[12] Divanoglu, S., U. (2008) SEÇIM KAMPANYALARINDA SIYASAL PAZARLAMA KARMASI ELEMANLARININ YERI VE ÖNEMI. Nigde Universitesi Iktisadi ve Idari Bilimler Fakultesi Dergisi, 1(2): 105-118.

[13] Gokcimen, S. (2008) “Ulkemizde Kadinlarin Siyasal Hayata Katilim Mucadelesi. Yasama Dergisi. (10) (Eylul,Ekim, Kasim, Aralik): 6-59. 
[14] Gorun, M. \& Kara. M. (2010) URBAN TRANSFORMATION AND ENHANCEMENT OF THE URBAN LIFE QUALITY IN THE CONTEXT OF SOCIAL ENTREPRENEURSHIP IN TURKEY. Journal of Administrative Sciences. 8(2): 139-164.

[15] Guler, B., K. (2011) SOCIAL ENTREPRENEURSHIP IN COMBATING WITH POVERTY: SOCIAL INNOVATIVE CASES OF ASHOKA FELLOWS. DEU Journal of GSSS, 13 (3): 79-111.

[16] Hotar, N. (2003) Gundem Disi Konusma. TBMM Tutanak Dergisi, (32): 24.

[17] ISLAMOGLU, A., H. (2002), Siyaset Pazarlaması Toplam Kalite Yaklaşımı, Beta Yayınclık, İstanbul.

[18] King, P. J. and Roberts, N. C. (1987) 'Policy Entrepreneurs: Catalysts for Policy Innovation', Journal of State Government, July-August: 172-178

[19] Kuyaksil, A. (2009) TURK ANAYASALARINDA KADIN HAKLARI VE GELISIMI. Mustafa Kemal University Journal of Social Sciences Institute. (6)11: 328-352.

[20] Leadbeater, C. (1997) The Rise of the Social Entrepreneur, Demos, London.

[21] Letts, C., Grossman, A., Ryan, W. (1999) High performance non-profit organizations: Managing upstream for greater impact, New York, Wiley.

[22] Lewis, E. (1980) Public 'Entrepreneurship: Toward a Theory of Bureaucratic Power', Indiana University Press, Bloomington IN.

[23] Mair, J., Marti, I. (2005) Social entrepreneurship research: A source of explanation, prediction, and delight. Journal of World Business, 41(1): 36-44.

[24] Mort, S., G., Weerawardena, J., Carneige, K. (2002) Social entrepreneurship: Towards conceptualization. International Journal of Nonprofit and Voluntary Sector Marketing, 8 (1): 76-88.

[25] Nicholls, A. (2010) The Legitimacy of Social Entrepreneurship: Reflexive Isomorphism in a Pre-Paradigmatic Field. Entrepreneurship Theory and Practice. 34(4): 611-633.

[26] Noruzi, M. R., Westover, J. H. \& Rahimi, R., G. (2010) An Explorations of Social Entrepreneurship in the Entrepreneurship Era. Asian Social Science, 6(6):3-10.

[27] PEREDO, Anna Maria ve Murdih MCLEAN; (2006), "Social Entrepreneurship: A Critical Review of the Concept", Journal of World Business, 41:56-65.

[28] Sanger, B., M., Levin, M. (1992) Using Old Stuff in New Ways, Innovation as a Case of Evolutionary Tinkering. Journal of Policy Analysis and Management, 10(4): 88-115.

[29] Seelos, C., Mair, J. (2005). Social entrepreneurship: Creating new business models to serve the poor. New Horizons, 48: 241-246.

[30] Soysal, A. (2010) Türkiye'de Kadın Girisimciler: Engeller ve Fırsatlar Bağlamında Bir Degerlendirme, Ankara Universitesi SBF Dergisi 65 (1):83-110.

[31] Thake, S., Zadek, S. (1997). Practical People, noble causes: How to support community-based social entrepreneurs. London: New Economic Foundation.

[32] THOMPSON, John L. ; (2002), "The World of the Social Entrepreneur", The International Journal of Public Sector Management, 15(5):412- 431.

[33] Wolk, A. (2008), Advancing Social Entrepreneurship Recemmendations for Policy Makers and Government Agencies, The Apsen Instutite Root Cause/MIT, Retrieved from www. aspeninstitute. org/ node/3099, Date: 12. 12. 2016. 